\title{
Article \\ Antibiotic and Heavy Metal Susceptibility of Non-Cholera Vibrio Isolated from Marine Sponges and Sea Urchins: Could They Pose a Potential Risk to Public Health?
}

\author{
Wellington Felipe Costa (D), Marcia Giambiagi-deMarval and Marinella Silva Laport *(D)
}

Citation: Costa, W.F.;

Giambiagi-deMarval, M.; Laport, M.S Antibiotic and Heavy Metal Susceptibility of Non-Cholera Vibrio Isolated from Marine Sponges and Sea Urchins: Could They Pose a Potential Risk to Public Health? Antibiotics 2021, 10, 1561. https://doi.org/10.3390/ antibiotics10121561

Academic Editors: Olumide Odeyemi and Deyan Stratev

Received: 30 November 2021 Accepted: 14 December 2021 Published: 20 December 2021

Publisher's Note: MDPI stays neutral with regard to jurisdictional claims in published maps and institutional affiliations.

Copyright: (c) 2021 by the authors. Licensee MDPI, Basel, Switzerland. This article is an open access article distributed under the terms and conditions of the Creative Commons Attribution (CC BY) license (https:// creativecommons.org/licenses/by/ $4.0 /)$.
Instituto de Microbiologia Paulo de Góes, Universidade Federal do Rio de Janeiro, Av. Carlos Chagas Filho, 373 , Cidade Universitária, Rio de Janeiro 21941-902, Brazil; wellfecosta@micro.ufrj.br (W.F.C.); marciagm@micro.ufrj.br (M.G.-d.)

* Correspondence: marinella@micro.ufrj.br; Tel.: +55-21-2560-8344

Abstract: Vibrio is an important human and animal pathogen that can carry clinically relevant antibiotic resistance genes and is present in different aquatic environments. However, there is a knowledge gap between antibiotic and heavy metal resistance and virulence potential when it is part of the microbiota from marine invertebrates. Here, we aimed to evaluate these characteristics and the occurrence of mobile genetic elements. Of 25 non-cholera Vibrio spp. from marine sponges and sea urchins collected at the coastlines of Brazil and France analyzed in this study, 16 (64\%) were non-susceptible to antibiotics, and two ( $8 \%$ ) were multidrug-resistant. Beta-lactam resistance (bla $\left.a_{\mathrm{SHV}}\right)$ and virulence $(v h h)$ genes were detected in sponge-associated isolates. The resistance gene for copper and silver $(c u s B)$ was detected in one sea urchin isolate. Plasmids were found in $11(44 \%)$ of the isolates. This new information allows a better comprehension of antibiotic resistance in aquatic environments, since those invertebrates host resistant Vibrio spp. Thus, Vibrio associated with marine animals may pose a potential risk to public health due to carrying these antibiotic-resistant genes.

Keywords: beta-lactamase; copper resistant; Darwinella; hemolysin; Paracentrotus lividus; Vibrio alginolyticus; Vibrio harveyi

\section{Introduction}

The genus Vibrio is a group of gram-negative bacilli possessing a curved-rod shape. They are ubiquitously distributed in aquatic environments, such as coastal seawater, sediments and estuaries, and are associated with marine invertebrate organisms [1]. Some species can be pathogenic for humans and aquatic animals (e.g., Vibrio cholerae, Vibrio alginolyticus, Vibrio parahaemolyticus, Vibrio vulnificus and Vibrio harveyi) [1,2]. In humans, Vibrio can cause mild to severe gastroenteritis, extra-gastrointestinal infections and sepsis, which can be fatal [2]. The bacteria are generally susceptible to antibiotics used in medical and veterinary practice. However, an increased number of resistant strains, non-cholera Vibrio, have been observed around the world [3].

Antibiotic-resistant Vibrio spp. strains, carrying clinically relevant antibiotic resistance genes (ARGs), have been isolated from marine environments [4-6]. Sometimes, these bacteria can also harbor virulence genes that increase their pathogenic potential $[7,8]$. These ARGs and virulence genes can be present on mobile genetic elements associated with heavy metal resistance genes (HMRGs). This mechanism allows the co-selection of bacteria carrying all three, ARGs, virulence genes and HMRGs, and facilitates their persistence and dissemination in environments contaminated with antibiotics and heavy metals [5-9].

Vibrio spp. is an essential member of the microbiota from marine sponges and sea urchins [10,11]. Information on the antibiotic resistance status of Vibrio spp. isolated from these invertebrates is still scarce. The "One Health" concept claims that the health of humans, animals and the environment be intrinsically connected [12]. Considering the 
co-selection potential of resistance and virulence mechanisms, marine invertebrates could be a source of non-cholera Vibrio strains that carry relevant (and maybe new) antibiotic resistance traits, which may contribute to the current global crisis in antibiotic resistance. On this background, we aimed to investigate if Vibrio associated with marine sponges and sea urchins could pose a potential risk to public health by characterizing the Vibrio spp. isolates phenotypically and genotypically in terms of antibiotic resistance, as well as the occurrence of heavy metal resistance genes, virulence genes and mobile genetic elements.

\section{Results}

\subsection{Identification of Vibrio spp.}

Of the 25 Vibrio spp. strains analyzed in this study, 19 were isolated from the Brazilian marine sponges Darwinella spp., Haliclona sp. and Plakina cyanorosea [13], and six from the gastrointestinal tract of the French sea urchin Paracentrotus lividus [10]. Previously, 14 strains were identified by $16 \mathrm{~S}$ rRNA sequencing as $V$. alginolyticus and one as $V$. harveyi $[10,13]$. MALDI-TOF MS analysis confirmed the identification of $10(67 \%)$ of the 15 potential pathogenic strains, with confidence at the genus level and likelihood at the species level. The remaining five (33\%) strains showed scores consistent with probable genus classification. However, the other strains $(n=10)$ identified as belonging to four distinct Vibrio species or only to the Vibrio genus by $16 \mathrm{~S}$ rRNA sequencing, using MALDITOF-MS, were identified as belonging only to three probable species. Among them were Vibrio parahaemolyticus $(n=2 ; 20 \%)$, Vibrio harveyi $(n=1 ; 10 \%)$ and Vibrio mytili $(n=1 ; 10 \%)$. Six $(60 \%)$ strains were not reliably identified (Table S1).

All species considered to be opportunistic human pathogens, such as $V$. alginolyticus and $V$. harveyi, were isolated from the marine sponges Darwinella spp. (sp.1 and sp. 2), Haliclona sp. and P. cyanorosea. The other species are rarely associated with human infection and were isolated from the marine sponges Darwinella sp. 2 and Haliclona sp. and from the sea urchin Paracentrotus lividus.

\subsection{Antibiotic Non-Susceptibility among Vibrio spp. Isolates}

A total of 16 (64\%) Vibrio spp. isolates were non-susceptible (resistant and/or intermediate) to one or more antibiotics, with two (8\%) strains of $V$. alginolyticus showing a MDR phenotype (Figure 1 and Table S1). All non-susceptible strains were isolated from marine sponges only.

The highest resistance rates found in the Vibrio spp. strains were for cephalexin $(n=9$, $36 \%)$ and erythromycin $(n=7,28 \%)$. Non-susceptibility was also observed for amikacin $(n=3,12 \%)$, ampicillin-sulbactam $(n=3,12 \%)$ and sulfamethoxazole-trimethoprim $(n=2$, $8 \%$ ), as well as for tobramycin, gentamicin, ofloxacin, ciprofloxacin, cefoxitin and amoxicillinclavulanic acid ( $n=1,4 \%$ for each one) (Figure 1$)$.

\subsection{Detection of Genotypes: Antibiotic and Heavy Metal Resistance Genes, Virulence Genes, and Integrons}

Among the four classes of antibiotics (aminoglycosides, $\beta$-lactams, macrolides and quinolones) investigated in this study, we found only one gene out of a total of 18 different targets of importance in medical practice. The antibiotic resistance gene bla $a_{\mathrm{SHV}}$, encoding a beta-lactamase, was detected in a single strain (V. alginolyticus 84BHI10) isolated from Darwinella sp. 2. With regard to the four heavy metal resistance genes tested, only cusB, which encodes resistance to copper and silver, was detected in just one isolate (Vibrio oceanisediminis P1I-2) from the P. lividus sea urchin. The virulence gene $v$ hh, encoding a hemolysin, was detected in just one strain (Vibrio sp. ME7) isolated from Haliclona sp. (Figure 1 and Supplementary Material Table S1). The intI1 gene, encoding the integrase from Class 1 integron, was not detected among the strains. 


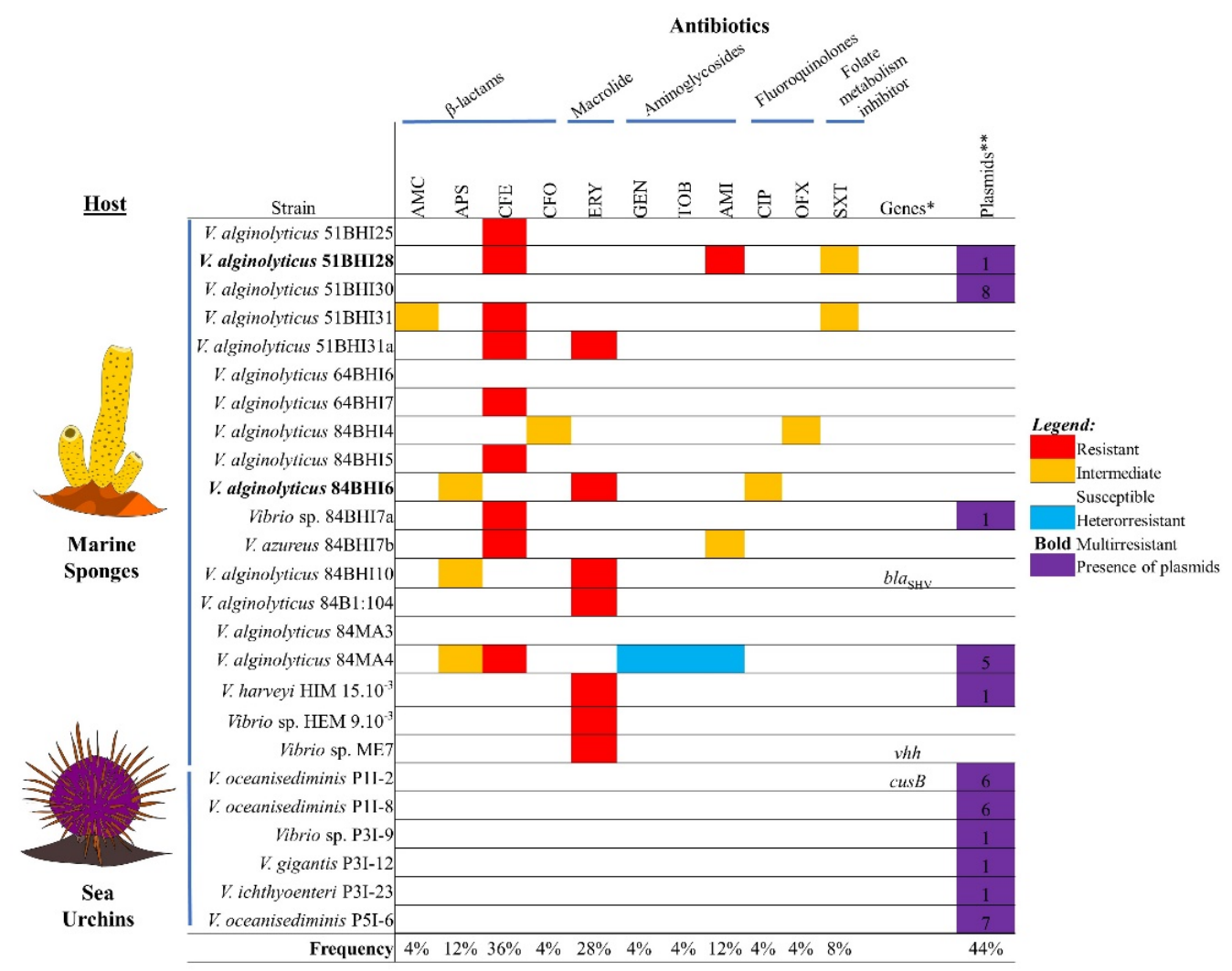

Figure 1. Non-susceptibility frequency of Vibrio spp. strains from marine sponges and sea urchins. The isolates were classified as resistant, multirresistant, intermediate, susceptible or heteroresistant to antibiotics. The antibiotic and heavy metal resistance genes, virulence genes $\left(^{*}\right)$ and number of plasmid forms $\left({ }^{* *}\right)$ detected were shown. AMC: amoxicillin-clavulanic acid; AMI: amikacin; APS: ampicillin-sulbactam; CFE: cephalexin; CFO: cefoxitin; CIP: ciprofloxacin; ERY: erythromycin; GEN: gentamicin; OFX: ofloxacin; SXT: trimethoprim/sulfamethoxazole; TOB: tobramycin.

\subsection{Plasmid Profile}

Plasmids were found in 11 (44\%) strains, which carried between one and eight different plasmids with sizes varying from 2.4 to $45.5 \mathrm{~kb}$ (Figure 1, Supplementary Materials: Table S1 and Figure S1). These mobile genetic elements occurred more frequently $(100 \%, n=6 / 6)$ in the French sea urchin isolates than in isolates from the Brazilian marine sponges $(26.3 \%$, $n=5 / 19)$.

\subsection{Association between Antibiotic Resistance Phenotypes and Occurrence of Plasmids}

Correlation analysis of the presence/absence of antibiotic resistance phenotype and presence/absence of plasmids for the 25 Vibrio spp. isolates indicated a moderate inverse correlation $(\mathrm{r}=-0.5014 ; p<0.05)$ of these characteristics. When considering only the 15 potentially pathogenic strains ( $V$. alginolyticus and $V$. harveyi), no correlation was observed between the antibiotic resistance phenotype and the occurrence of plasmids $(\mathrm{r}=-0.0753$; $p>0.05)$.

\section{Discussion}

In this study, we aimed to investigate the possibility that Vibrio spp. associated with marine sponges and sea urchins may pose a risk for public health. With this objective, the non-cholera Vibrio strains were reidentified by MALDI-TOF MS and characterized phenotypically and genotypically with regard to antimicrobial resistance, as well as to the occurrence of heavy metal resistance genes, virulence genes and mobile genetic elements.

Currently, there are 157 validated Vibrio species according to the Genome Taxonomy Database (GTDB; available online: https://gtdb.ecogenomic.org/stats/r95; accessed on 9 
December 2021). From these, Vibrio cholerae, Vibrio vulnificus, Vibrio parahaemolyticus and Vibrio alginolyticus are the four species, also known as the "big four", often associated with human infections [2]. In this study, among the six distinct species that were previously identified [10-13], two species were confirmed by MALDI-TOF MS. Identification and discrimination of closely related Vibrio spp. can be difficult and some strategies are limited in terms of the identification of environmental species [14,15]. MALDI-TOF-MS is primarily designed for clinical use, and thus, the Biotyper database mainly contains clinically important species [16]. The performance of this method depends on the strain catalogue in the reference library. However, the Bruker standard library satisfied the requirements of our work proposal to confirm the identification of potentially pathogenic species.

The role of the marine environment in the development and dissemination of antibiotic resistance is largely unknown. Vibrio spp. are indigenous to the sea, and in recent years, the occurrence of resistance genes in several species has been observed [6,15]. Herein, we observed that $V$. alginolyticus, previously described as a potential pathogen, was the most frequent species with an antibiotic non-susceptibility phenotype. Other studies demonstrated high resistance rates of $V$. alginolyticus strains isolated from marine animals, with MDR strains showing the ability to transfer ARGs to susceptible strains $[17,18]$. Moreover, evidence that sponges support bacterial horizontal gene transfer was recently described [19]. Therefore, MDR Vibrio spp. strains are being hosted by marine invertebrates and may act in the dissemination of ARGs.

Regarding resistance phenotypes, Vibrio spp. are intrinsic carriers of the CARB family of penicillinases. This beta-lactamases cannot efficiently hydrolyze the early cephalosporins, such as cephalexin, and therefore produce a resistance phenotype [20]. Cephalexin-resistant strains were found to be negative, by means of PCR testing, for the tested beta-lactamase resistance genes, which could indicate that different (or new) mechanisms of cephalexin resistance could be involved in the observed phenotype. Furthermore, Vibrio can be intrinsically resistant to erythromycin since the outer membrane can act as a physical barrier that would make it difficult for the macrolide to enter the bacterial cell [21]. However, acquired macrolide resistance genes, which are important in medical practice, have been described in Vibrio spp. and are known to be carried by erythromycin-susceptible strains [4].

Interestingly, antibiotic non-susceptible strains occurred exclusively in Brazilian marine sponges, while plasmids occurred more frequently among strains isolated from the French sea urchins. The antibiotic resistance phenotype and plasmid occurrence correlated inversely. However, we cannot discard the possibility that the place of isolation of the marine organisms, a coastal region with high anthropogenic pressure, could influence the presence of these mobile genetic elements in Vibrio spp. Moreover, none of the isolates were positive for integron class 1, (intI1). Thus, our results suggest that the antibiotic resistance phenotypes were not related to plasmid and/or class 1 integron occurrence, as observed in another study [22]. This lack of relationship could indicate that resistance genotypes can be integrated into the chromosomes and/or into another type of integrative element. In Vibrio spp., superintegrons $(\sim 120 \mathrm{~kb})$ are common and are dynamic in the acquisition and release of gene cassettes due to their IntIA integrase performance, which has 45 to $50 \%$ similarity with IntI1 to IntI3 [1]. Furthermore, Vibrio spp. plasmids may be related to other functions besides carrying ARGs, such as encoding antigenic variation to evade the host's immune system, proteins or siderophores associated with iron uptake, and adaptation to environments contaminated by heavy metals [1,18].

Some of the highlights of the present study were the detection of bla $a_{\mathrm{SHV}}$, vhh and cusB in the marine invertebrate-Vibrio spp. strains V. alginolyticus 84BHI10, Vibrio sp. ME7 and $V$. oceanisediminis P1I-2, respectively. The bla $\mathrm{SHV}$ gene encodes a family of beta-lactamases with more than 220 members, according to the Beta-lactamase Database (http:/ / www.bldb.eu/, accessed on 7 November 2021). These beta-lactamases are able to hydrolyze penicillins, extended-spectrum cephalosporins and monobactams, but are susceptible to inhibition by beta-lactamase inhibitors. However, the bla $a_{\mathrm{SHV}}$ carrying strain demonstrated an intermediate resistance phenotype to ampicillin-sulbactam. A variant 
enzyme, SHV-10, that is not inhibited by beta-lactamase inhibitors has been described, but lost the ability to hydrolyze cephalosporins, showing catalytic activity only for penicillins [23]. Thus, the marine sponge-associated strain could be carrying the SHV-10 or a new SHV variant not inhibited by beta-lactamase inhibitors. Similar characteristics were described by another study, conducted by our group, on a Shewanella sp. strain isolated from the sea urchin P. lividus [24]. These reports configure the first descriptions of bla $a_{\mathrm{SHV}}$ in bacteria from marine sponges and sea urchins, reinforcing the role of Vibrio spp. as ARGs' reservoir in marine invertebrates.

The detection of wh in Vibrio sp. ME7 from marine sponge is very interesting, because the wh gene encodes a hemolysin protein, a potent virulence factor involved in pathogenicity from most $V$. harveyi in a range of fish and shellfish species [25]. The presence of this gene confirms the pathogenic potential of this isolate, whether $V$. coralliilyticus or $V$. harveyi, since both identification methods used presented low scores for species identification. However, considering $v$ hh as a molecular marker of $V$. harveyi [25], there is a strong possibility of this strain belonging to this species. Alternatively, these low scores $(<2.300)$ and identities $(<95 \%)$ may indicate a novel Vibrio species. With regard to the closest species, $V$. coralliilyticus is a well-known pathogen of corals that is responsible for tissue lysis, bleaching and imperative losses of coral reefs worldwide [26]. Moreover, this species has shown the capacity to infect fish and oysters, with an enormous virulence gene repertoire, including encoders of hemolysins/cytolysins $[27,28]$. In the same line, $V$. harveyi represents a serious pathogen of marine animals, specially of cultured marine fish, causing diseases responsible for severe economic losses in the aquaculture industry [29]. Various virulence factors were already detected in $V$. harveyi strains isolated from lesions of marine fish, with high frequency of hemolysins/cytolysins (vhh, vvh and $h l y A)[7,8]$. Despite scarce information of this species leading to human infection, their pathogenic potential in marine animals is imperative, suggesting that Vibrio sp. ME7 has pathogenic capacity to cause human and sponge disease. However, more research is needed since ME7 was found to be erythromycin resistant. Therefore, this finding suggests that marine sponges can act as host reservoirs for antibiotic-resistant animal pathogens.

In relation to HMRGs, the cusB gene (copper and silver resistance encoder) was detected in the plasmid carrier $V$. oceanisediminis P1I-2 isolated from one sea urchin specimen (P. lividus). This specimen was the same as that from which Shewanella sp. cited above (also a $c$ s B carrier) was isolated $[10,24]$. Thus, our results can suggest that the habitat of these sea urchins (Aber, France) may be contaminated by toxic metals, such as copper and/or silver, and that bacteria carrying heavy-metal resistance genes could be selected in these marine invertebrates.

The fact that other ARGs for a given phenotype were not detected by PCR in this work suggests that further antibiotic resistance mechanisms (which may be unknown) could be involved in the observed phenotypes. Similar observations of the non-detection of ARGs for a given phenotype have also been reported by other studies [24,30]. Such mechanisms, added to the resistance and virulence genes detected here, may represent (new) risks for public health, since Vibrio spp. of marine sponges and sea urchins could eventually act as donors of these genes to other bacteria from microbiota of these invertebrates. The close contact between them could allow this. Therefore, such genes could reach other bacteria and new habitats, such as humans and animals, leading to the worsening of the antibiotic resistance crisis [19].

\section{Materials and Methods}

\subsection{Bacterial Isolates}

Twenty-five Vibrio spp. were selected based on their viability and analyzed from a culture collection isolated from two phyla of marine invertebrate organisms. Nineteen strains were isolated from the Brazilian marine sponges Darwinella spp., Haliclona sp. and Plakina cyanorosea as described [13]. The other six strains were isolated from the gastrointestinal tract of the French sea urchin Paracentrotus lividus as described [10]. Briefly, 
all sponge-Vibrio spp. strains were isolated on brain heart infusion (BHI) agar and marine agar, tenfold diluted or not, while urchin-Vibrio spp. strains were isolated on marine agar or tenfold-diluted marine agar, and both mediums were supplemented with $10 \mu \mathrm{g} / \mathrm{mL}$ cycloheximide and incubated at $25^{\circ} \mathrm{C}[10,13]$. The reactivation of strains for the present analysis occurred under the same conditions and using the same culture mediums as those of the original isolation. All isolates were previously identified by $16 \mathrm{~S}$ rRNA sequencing as Vibrio alginolyticus (14), Vibrio azureus (1), Vibrio gigantis (1), Vibrio harveyi (1), Vibrio ichthyoenteri (1), Vibrio oceanisediminis (3) and Vibrio spp. (4) (Table S1) [10,13].

\subsection{MALDI-TOF MS Identification}

Vibrio spp. isolates were also identified by Matrix-Assisted Laser Desorption/ Ionization-time-of-flight mass spectrometry (MALDI-TOF MS) on a Microflex LT MS platform (Bruker Daltonics) with the samples being prepared as previously described [13]. The mass spectra obtained were compared to the references in the database using MALDI Biotyper 7.0 (Bruker $^{\circledR}$ ) software. Score values considered for identification were those recommended by the manufacturer: $\geq 2.300$ indicated confidence at the species level; 2.299-2.000 at the genus level and likely for the species level; 1.700-1.999 solely at the genus level; and <1.699 was considered not reliable for identification.

\subsection{Antibiotic Susceptibility Profiling}

Antibiotic susceptibility was determined by means of the disc-diffusion method according to the Clinical and Laboratory Standards Institute [31]. Twenty-three antibiotic discs (Sensidisc, São Paulo, Brazil) of the $\beta$-lactams (amoxicillin-clavulanic acid (30 $\mu \mathrm{g})$, ampicillin-sulbactam $(20 \mu \mathrm{g})$, piperacillin-tazobactam $(110 \mu \mathrm{g})$, aztreonam $(30 \mu \mathrm{g})$, cefepime $(30 \mu \mathrm{g})$, cefoxitin $(30 \mu \mathrm{g})$, ceftazidime $(30 \mu \mathrm{g})$, ceftriaxone $(30 \mu \mathrm{g})$, cephalexin $(30$ $\mu \mathrm{g})$, ertapenem $(10 \mu \mathrm{g})$, imipenem $(10 \mu \mathrm{g})$, meropenem $(10 \mu \mathrm{g}))$, aminoglycosides (gentamicin $(10 \mu \mathrm{g})$, amikacin $(30 \mu \mathrm{g})$, tobramycin $(10 \mu \mathrm{g}))$, fluoroquinolones (nalidixic acid $(30 \mu \mathrm{g})$, ciprofloxacin $(5 \mu \mathrm{g})$, levofloxacin $(5 \mu \mathrm{g})$, ofloxacin $(5 \mu \mathrm{g}))$, folate metabolism inhibitor (trimethoprim-sulfamethoxazole $(1.25-23.75 \mu \mathrm{g}))$, macrolide (erythromycin $(15 \mu \mathrm{g})$ ), phenicol (chloramphenicol $(30 \mu \mathrm{g})$ ), and tetracycline (tetracycline $(30 \mu \mathrm{g})$ ) classes or groups were selected. The quality control strains Escherichia coli ATCC ${ }^{\circledR} 25922$ and Escherichia coli ATCC $^{\circledR} 35218$ (for $\beta$-lactam/ $\beta$-lactamase inhibitor discs), and the susceptibility interpretation criteria used were as described in CLSI [31] with modifications according to da Costa et al. [24]. Multidrug-resistance (MDR) was defined as acquired non-susceptibility to at least one agent of three or more antibiotic categories [32]. The heteroresistance phenotype was characterized when a purified strain showed growth of resistant colonies within the inhibition zone [33].

\subsection{Genomic and Plasmid DNA Extractions}

Genomic DNA was obtained using the UltraClean Microbial DNA Isolation kit (Mo Bio, Carlsbad, CA, USA) and stored at $-20{ }^{\circ} \mathrm{C}$ until use for PCR amplification. Plasmid DNA was prepared employing Wizard Plus SV Minipreps DNA Purification Systems (Promega, Madison, WI, USA). Klebsiella pneumoniae Kp13 plasmids [34] were used as molecular size markers for plasmids.

\subsection{PCR Assays}

Strains were screened by PCR amplification for ARGs encoding resistance to betalactams $\left(b l a_{\mathrm{TEM}}, b l a_{\mathrm{SHV}}, b l a_{\mathrm{GES}}\right)$, aminoglycosides $\left(\operatorname{aac}\left(6^{\prime}\right)-I e-a p h\left(2^{\prime}\right)-I a\right.$, aac $\left(6^{\prime}\right)-I b$, ant $\left.\left(2^{\prime \prime}\right)-I\right)$, macrolides $(m e f(C), \operatorname{mph}(\mathrm{G}), \operatorname{erm} B, \operatorname{ere} A, \operatorname{mph} A, \operatorname{mef} A)$ and quinolones $(q n r A, q n r B, q n r C$, $q n r D, q n r S, q n r V C)$ for stains that showed the respective resistance phenotypes. At the same time, all 25 strains were screened by PCR amplification for HMRGs encoding resistance to cadmium ( $c a d A)$, copper $(c z c B, c u s B)$, lead ( $p b r A)$ and mercury (mer $A)$, virulence genes encoding hemolysins (tox $R, t d h, t r h, v h h)$ and type VI secretion systems (T6SS), and genes encoding the integrase from Class 1 integron (intI1). Multiplex PCR reactions were 
performed for ARGs encoding resistance to beta-lactams (beta-lactamase-coding genes) and quinolones (Qnr-coding genes) [24].

PCR was conducted in a total volume of $25 \mu \mathrm{L}$ as described [24]. All primer sequences and amplification conditions were taken from their respective references (Table S2). Genomic DNA from strains of Vibrio parahaemolyticus IOC $17381\left(t o x R^{+}\right.$and $\left.t d h^{+}\right)$and 0798081 $\left(t r h^{+}\right)$were used as positive controls for the respective virulence genes targeted by PCR [35]. Amplicons were observed through 1-2\% agarose gel electrophoresis using the Low DNA Mass Ladder (Thermo Fisher Scientific, Waltham, MA, USA) as the molecular size standard.

\subsection{Verification of Antibiotic Resistance Phenotype and Plasmids Association}

The correlation between the antimicrobial resistance phenotype and the presence of plasmids was assessed for all strains together and for the 15 potentially pathogenic strains ( $V$. alginolyticus and $V$. harveyi) separately. The Pearson's correlation coefficients were calculated with 95\% confidence intervals using GraphPad Prism software, version 8.0.2.

\section{Conclusions}

With the advance of the antimicrobial resistance crisis, non-cholera Vibrio strains are being investigated as resistance gene reservoirs in aquatic environments. Our study revealed that marine sponges and sea urchins in natural environments are harboring antimicrobial-resistant Vibrio spp., which carry important and maybe new antimicrobial and heavy metal resistance genes, as well as virulence genes and plasmids. These findings corroborate that Vibrio spp. associated with marine sponges and sea urchins may pose a potential risk to public health. These aquatic animals can act as an antimicrobial-resistantand pathogenic-Vibrio spp. reservoir in the environment. Further investigations may reveal antimicrobial resistance genotypes that are not possible to detect using PCR methodologies and demonstrate the genetic environment of ARGs and virulence genes, thereby increasing the analytic power of the resistome, virulome and mobilome of non-cholera Vibrio strains from the environment and leading to potential further consequences for public health.

Supplementary Materials: The following are available online at https:/ /www.mdpi.com/article/10 .3390/antibiotics10121561/s1, Figure S1: Plasmid profile of the Vibrio spp. strains, Table S1: Identification, antimicrobial resistance profile, antimicrobial and heavy metal resistance genes, virulence genes and the plasmid profile of Vibrio spp. isolates from marine sponges (Brazil) and sea urchins (France), Table S2: Primers used in this study. References [25,36-52] are cited in the supplementary materials

Author Contributions: Conceptualization, W.F.C., M.G.-d. and M.S.L.; Methodology, W.F.C. and M.S.L.; Validation, W.F.C., M.G.-d. and M.S.L.; Formal Analysis, W.F.C., M.G.-d. and M.S.L.; Investigation, W.F.C. and M.S.L.; Resources, M.G.-d. and M.S.L.; Data Curation, W.F.C., M.G.-d. and M.S.L.; Writing_-Original Draft Preparation, W.F.C. and M.S.L.; Writing-Review and Editing, W.F.C., M.G.-d. and M.S.L.; Visualization, W.F.C., M.G.-d. and M.S.L.; Supervision, M.G.-d. and M.S.L.; Project Administration, M.G.-d. and M.S.L.; Funding Acquisition, M.G.-d. and M.S.L. All authors have read and agreed to the published version of the manuscript.

Funding: This research was funded by Fundação de Amparo à Pesquisa do Estado do Rio de Janeiro (E-26/203.320/2017; E-26/010.101056/2018; E-26/010.001463/2019; E-26/211.554/2019 (Programa Rede de Pesquisa em Saúde); E-26/201.191/2020 and 26/200.948/2021); Coordenação de Aperfeiçoamento de Pessoal de Nível Superior-Brasil (Finance Code 001); and Conselho Nacional de Desenvolvimento Científico e Tecnológico (305940/2018-0; 306395/2020-7).

Institutional Review Board Statement: Not applicable.

Informed Consent Statement: Not applicable.

Data Availability Statement: Not applicable.

Acknowledgments: We are grateful to Renata Cristina Picão for granting beta-lactamase encoding genes' primers for PCR and control strains for the antimicrobial resistance genes' PCRs. We are also grateful to Wanda von Krüger for kindly granting control strains for the virulence genes' PCRs. The 
authors give special thanks to Walter Oelemann and Rafaela L.S. Rodrigues for their assistance in the preparation of this manuscript.

Conflicts of Interest: The authors declare no conflict of interest.

\section{References}

1. Boyd, E.F.; Carpenter, M.R.; Chowdhury, N.; Cohen, A.L.; Haines-Menges, B.L.; Kalburge, S.S.; Kingston, J.J.; Lubin, J.B.; Ongagna-Yhombi, S.Y.; Whitaker, W.B. Post-genomic analysis of members of the family Vibrionaceae. Microbiol. Spectr. 2015, 3 , 1-26. [CrossRef] [PubMed]

2. Baker-Austin, C.; Oliver, J.D.; Alam, M.; Ali, A.; Waldor, M.K.; Qadri, F.; Martinez-Urtaza, J. Vibrio spp. infections. Nat. Rev. Dis. Primers 2018, 4, 1-19. [CrossRef]

3. Elmahdi, S.; Da Silva, L.V.; Parveen, S. Antibiotic resistance of Vibrio parahaemolyticus and Vibrio vulnificus in various countries: A review. Food Microbiol. 2016, 57, 128-134. [CrossRef] [PubMed]

4. Fri, J.; Ndip, R.N.; Njom, H.A.; Clarke, A.M. Antibiotic susceptibility of non-cholera Vibrios isolated from farmed and wild marine fish (Argyrosomus japonicus), implications for public health. Microb. Drug. Resist. 2018, 24, 1296-1304. [CrossRef] [PubMed]

5. Canellas, A.L.B.; da Costa, W.F.; Paranhos, R.; Laport, M.S. Diving into the unknown: Identification of antimicrobial resistance hotspots in a tropical urban estuary. Lett. Appl. Microbiol. 2021, 73, 270-279. [CrossRef]

6. Canellas, A.L.B.; Lopes, I.R.; Mello, M.P.; Paranhos, R.; de Oliveira, B.F.R.; Laport, M.S. Vibrio species in an urban tropical estuary: Antimicrobial susceptibility, interaction with environmental parameters, and possible public health outcomes. Microorganisms 2021, 9, 1007. [CrossRef]

7. Deng, Y.; Xu, H.; Su, Y.; Liu, S.; Xu, L.; Guo, Z.; Wu, J.; Cheng, C.; Feng, J. Horizontal gene transfer contributes to virulence and antibiotic resistance of Vibrio harveyi 345 based on complete genome sequence analysis. BMC Genom. 2019, 20, 761. [CrossRef]

8. Deng, Y.; Xu, L.; Liu, S.; Wang, Q.; Guo, Z.; Chen, C.; Feng, J. What drives changes in the virulence and antibiotic resistance of Vibrio harveyi in the South China Sea? J. Fish Dis. 2020, 43, 853-862. [CrossRef]

9. Lloyd, N.A.; Janssen, S.E.; Reinfelder, J.R.; Barkay, T. Co-selection of mercury and multiple antibiotic resistances in bacteria exposed to mercury in the Fundulus heteroclitus gut microbiome. Curr. Microbiol. 2016, 73, 834-842. [CrossRef]

10. Laport, M.S.; Bauwens, M.; Collard, M.; George, I. Phylogeny and antagonistic activities of culturable bacteria associated with the gut microbiota of the sea urchin (Paracentrotus lividus). Curr. Microbiol. 2018, 75, 359-367. [CrossRef]

11. Laport, M.S. Isolating bacteria from sponges: Why and how? Curr. Pharm. Biotechnol. 2017, 18, 1224-1236. [CrossRef]

12. World Health Organization. What Is 'One Health'? Available online: https://www.who.int/news-room/q-a-detail/one-health (accessed on 27 November 2021).

13. Freitas-Silva, J.; Silva-Oliveira, T.; Muricy, G.; Laport, M.S. Bacillus strains associated to Homoscleromorpha sponges are highly active against multidrug resistant bacteria. Curr. Microbiol. 2020, 77, 807-815. [CrossRef]

14. Eddabra, R.; Prévost, G.; Scheftel, J.-M. Rapid discrimination of environmental Vibrio by matrix-assisted laser desorption ionization time-of-flight mass spectrometry. Microbiol. Res. 2012, 167, 226-230. [CrossRef]

15. Håkonsholm, F.; Lunestad, B.T.; Aguirre Sánchez, J.R.; Martinez-Urtaza, J.; Marathe, N.P.; Svanevik, C.S. Vibrios from the Norwegian marine environment: Characterization of associated antibiotic resistance and virulence genes. Microbiologyopen 2020, 9, 1093. [CrossRef] [PubMed]

16. Santos, I.C.; Hildenbrand, Z.L.; Schug, K.A. Applications of MALDI-TOF MS in environmental microbiology. Analyst 2016, 141, 2827-2837. [CrossRef]

17. Hernández-Robles, M.F.; Álvarez-Contreras, A.K.; Juárez-García, P.; Natividad-Bonifacio, I.; Curiel-Quesada, E.; Vázquez-Salinas, C.; Quiñones-Ramírez, E.I. Virulence factors and antimicrobial resistance in environmental strains of Vibrio alginolyticus. Int. Microbiol. 2016, 19, 191-198. [CrossRef] [PubMed]

18. Zheng, Z.; Li, R.; Ye, L.; Chan, E.W.-C.; Chen, S. Identification and characterization of IncA/C conjugative, bla $a_{\mathrm{NDM}-1-\mathrm{bearing}}$ plasmid in Vibrio alginolyticus of food origin. Antimicrob. Agents Chemother. 2018, 62, e01897-18. [CrossRef] [PubMed]

19. Cartwright, A.; Arnscheidt, J.; Conwell, M.; Dooley, J.S.G.; McGonigle, C.; Naughton, P.J. Effects of freshwater sponge Ephydatia fluviatilis on conjugative transfer of antimicrobial resistance in Enterococcus faecalis strains in aquatic environments. Lett. Appl. Microbiol. 2020, 71, 39-45. [CrossRef]

20. Chiou, J.; Li, R.; Chen, S. CARB-17 family of $\beta$-lactamases mediates intrinsic resistance to penicillins in Vibrio parahaemolyticus. Antimicrob. Agents Chemother. 2015, 59, 3593-3595. [CrossRef] [PubMed]

21. Krishnamoorthy, G.; Leus, I.V.; Weeks, J.W.; Wolloscheck, D.; Rybenkov, V.V.; Zgurskaya, H.I. Synergy between active efflux and outer membrane diffusion defines rules of antibiotic permeation into Gram-negative bacteria. MBio 2017, 8, e01172-17. [CrossRef]

22. Sulca, M.A.; Orozco, R.; Alvarado, D.E. Antimicrobial resistance not related to 1, 2, 3 integrons and Superintegron in Vibrio spp. isolated from seawater sample of Lima (Peru). Mar. Pollut. Bull. 2018, 131, 370-377. [CrossRef]

23. Prinarakis, E.E.; Miriagou, V.; Tzelepi, E.; Gazouli, M.; Tzouvelekis, L.S. Emergence of an inhibitor-resistant beta-lactamase (SHV-10) derived from an SHV-5 variant. Antimicrob. Agents Chemother. 1997, 41, 838-840. [CrossRef] [PubMed]

24. da Costa, W.F.; Giambiagi-deMarval, M.; Laport, M.S. Shewanella harboring antimicrobial and copper resistance genes in sea urchins (Paracentrotus lividus) from the Crozon peninsula (Brittany, France). Infect. Genet. Evol. 2020, 85, 104437. [CrossRef] [PubMed] 
25. Conejero, M.J.U.; Hedreyda, C.T. PCR detection of hemolysin (vhh) gene in Vibrio harveyi. J. Gen. Appl. Microbiol. 2004, 50, 137-142. [CrossRef]

26. Ben-Haim, Y.; Zicherman-Keren, M.; Rosenberg, E. Temperature-regulated bleaching and lysis of the coral Pocillopora damicornis by the novel pathogen Vibrio coralliilyticus. Appl. Environ. Microbiol. 2003, 69, 4236-4242. [CrossRef]

27. Austin, B.; Austin, D.; Sutherland, R.; Thompson, F.; Swings, J. Pathogenicity of vibrios to rainbow trout (Oncorhynchus mykiss, Walbaum) and Artemia nauplii. Environ. Microbiol. 2005, 7, 1488-1495. [CrossRef]

28. Kim, H.J.; Jun, J.W.; Giri, S.S.; Chi, C.; Yun, S.; Kim, S.G.; Park, S.C. Identification and genome analysis of Vibrio coralliilyticus causing mortality of Pacific oyster (Crassostrea gigas) larvae. Pathogens 2020, 9, 206. [CrossRef] [PubMed]

29. Gomez-Gil, B.; Soto-Rodríguez, S.; García-Gasca, A.; Roque, A.; Vazquez-Juarez, R.; Thompson, F.L.; Swings, J. Molecular identification of Vibrio harveyi-related isolates associated with diseased aquatic organisms. Microbiology 2004, 150, $1769-1777$. [CrossRef] [PubMed]

30. Bier, N.; Schwartz, K.; Guerra, B.; Strauch, E. Survey on antimicrobial resistance patterns in Vibrio vulnificus and Vibrio cholerae non-O1/non-O139 in Germany reveals carbapenemase-producing Vibrio cholerae in coastal waters. Front. Microbiol. 2015, 6, 1179. [CrossRef]

31. CLSI. Performance standards for antimicrobial susceptibility testing. In Clinical and Laboratory Standards Institute, 31st ed.; CLSI: Wayne, PA, USA, 2021.

32. Magiorakos, A.P.; Srinivasan, A.; Carey, R.B.; Carmeli, Y.; Falagas, M.E.; Giske, G.C.; Harbarth, S.; Hindler, J.F.; Kahlmeter, G.; Olsson-Liljequist, B.; et al. Multidrug-resistant, extensively drug-resistant and pandrug-resistant bacteria: An international expert proposal for interim standard definitions for acquired resistance. Clin. Microbiol. Infect. 2012, 8, 268-281. [CrossRef]

33. Andersson, D.I.; Nicoloff, H.; Hjort, K. Mechanisms and clinical relevance of bacterial heteroresistance. Nat. Rev. Microbiol. 2019, 17, 479-496. [CrossRef]

34. Ramos, P.I.P.; Picão, R.C.; Almeida, L.G.P.; Lima, N.C.B.; Girardello, R.; Vivan, A.C.P.; Xavier, D.E.; Barcellos, F.G.; Pelisson, M.; Vespero, E.C.; et al. Comparative analysis of the complete genome of KPC-2-producing Klebsiella pneumoniae Kp13 reveals remarkable genome plasticity and a wide repertoire of virulence and resistance mechanisms. BMC Genom. 2017, 15, 54. [CrossRef] [PubMed]

35. Santos, L.O.; de Lanna, C.A.; Arcanjo, A.C.C.; Bisch, P.M.; von Krüger, W.M.A. Genotypic diversity and pathogenic potential of clinical and environmental Vibrio parahaemolyticus isolates from Brazil. Front. Microbiol. 2021, 12, 602653. [CrossRef]

36. Campana, E.H.; Xavier, D.E.; Petrolini, F.V.; Cordeiro-Moura, J.R.; Araujo, M.R.; Gales, A.C. Carbapenem-resistant and cephalosporin-susceptible: A worrisome phenotype among Pseudomonas aeruginosa clinical isolates in Brazil. Braz. J. Infect. Dis. 2017, 21, 57-62. [CrossRef] [PubMed]

37. Schiwon, K.; Arends, K.; Rogowski, K.M.; Fürch, S.; Prescha, K.; Sakinc, T.; Van Houdt, R.; Werner, G.; Grohmann, K. Comparison of antibiotic resistance, biofilm formation and conjugative transfer of Staphylococcus and Enterococcus isolates from International Space Station and Antarctic Research Station Concordia. Microb. Ecol. 2013, 65, 638-651. [CrossRef] [PubMed]

38. Park, C.H.; Robicsek, A.; Jacoby, G.A.; Sahm, D.; Hooper, D.C. Prevalence in the United States of $a a c\left(6^{\prime}\right)-I b-c r$ encoding a ciprofloxacin-modifying enzyme. Antimicrob. Agents Chemother. 2006, 50, 3953-3955. [CrossRef] [PubMed]

39. Heuer, H.; Krögerrecklenfort, E.; Wellington, E.M.H.; Egan, S.; van Elsas, J.D.; van Overbeek, L.; Collard, J.-M.; Guillaume, G.; Karagouni, A.D.; Nikolakopoulou, T.L.; et al. Gentamicin resistance genes in environmental bacteria: Prevalence and transfer. FEMS Microbiol. Ecol. 2002, 42, 289-302. [CrossRef]

40. Nonaka, L.; Maruyama, F.; Suzuki, S.; Masuda, M. Novel macrolide-resistance genes, mef(C) and mph(G), carried by plasmids from Vibrio and Photobacterium isolated from sediment and seawater of a coastal aquaculture site. Lett. Appl. Microbiol. 2015, 61, 1-6. [CrossRef] [PubMed]

41. Jensen, L.B.; Frimodt-Møller, N.; Aarestrup, F.M. Presence of erm gene classes in gram-positive bacteria of animal and human origin in Denmark. FEMS Microbiol. Lett. 1999, 170, 151-158. [CrossRef] [PubMed]

42. Sutcliffe, J.; Grebe, T.; Kamradt, A.T.; Wondrack, L. Detection of erythromycin resistant determinants by PCR. Antimicrob. Agents Chemother. 1996, 40, 2562-2566. [CrossRef]

43. Luna, V.A.; Cousin, S., Jr.; Whittington, W.L.H.; Roberts, M.C. Identification of the conjugative mef gene in clinical Acinetobacter junii and Neisseria gonorrhoeae isolates. Antimicrob. Agents Chemother. 2000, 44, 2503-2506. [CrossRef]

44. Kraychete, G.B.; Botelho, L.A.B.; Campana, E.H.; Picão, R.C.; Bonelli, R.R. Updated multiplex PCR for detection of all six plasmid-mediated qnr gene families. Antimicrob. Agents Chemother. 2016, 60, 7524-7526. [CrossRef] [PubMed]

45. De, J.; Ramaiah, N.; Vardanyan, L. Detoxification of toxic heavy metals by marine bacteria highly resistant to mercury. Mar. Biotechnol. 2008, 10, 471-477. [CrossRef] [PubMed]

46. Deredjian, A.; Colinon, C.; Brothier, E.; Favre-Bonté, S.; Cournoyer, B.; Nazaret, S. Antibiotic and metal resistance among hospital and outdoor strain of Pseudomonas aeruginosa. Res. Microbiol. 2011, 162, 689-700. [CrossRef] [PubMed]

47. Khan, Z.; Nisar, M.A.; Hussain, S.Z.; Arshad, M.N.; Rehman, A. Cadmium resistance mechanism in Escherichia coli P4 and its potential use to bioremediate environmental cadmium. Appl. Microbiol. Biotechnol. 2015, 99, 10745-10757. [CrossRef]

48. Oger, C.; Bertheb, T.; Quilleta, L.; Barraya, S.; Chiffoleauc, J.F.; Petit, F. Estimation of the abundance of the cadmium resistance gene $c a d A$ in microbial communities in polluted estuary water. Res. Microbiol. 2001, 152, 671-678. [CrossRef]

49. Borremans, B.; Hobman, J.L.; Provoost, A.; Brown, N.L.; van-Der-Lelie, D. Cloning and functional analysis of the $p b r$ lead resistance determinant of Ralstonia metallidurans CH34. J. Bacteriol. 2001, 183, 5651-5658. [CrossRef] [PubMed] 
50. Guin, S.; Saravanan, M.; Chowdhury, G.; Pazhani, G.P.; Ramamurthy, T.; Das, S.C. Pathogenic Vibrio parahaemolyticus indiarrhoeal patients, fish and aquatic environments and their potential for inter-source transmission. Heliyon 2019, 5, 01743. [CrossRef]

51. Chao, G.; Jiao, X.; Zhou, X.; Wang, F.; Yang, Z.; Huang, Z.; Pan, Z.; Zhou, L.; Qian, X. Distribution of genes encoding four pathogenicity islands (VPaIs), T6SS, biofilm, and type I pilus in food and clinical strains of Vibrio parahaemolyticus in China. Foodborne Pathog. Dis. 2010, 7, 649-658. [CrossRef]

52. Jiang, H.; Yu, T.; Yang, Y.; Yu, S.; Wu, J.; Lin, R.; Li, Y.; Fang, J.; Zhu, C. Co-occurrence of antibiotic and heavy metal resistance and sequence type diversity of Vibrio parahaemolyticus isolated from Penaeus vannamei at freshwater farms, seawater farms, and markets in Zhejiang Province, China. Front. Microbiol. 2020, 11, 1294. [CrossRef] [PubMed] 